\title{
Spatial Redistribution of Nitrogen by Cattle in Semiarid Rangeland
}

\author{
David J. Augustine, ${ }^{1}$ Daniel G. Milchunas, ${ }^{2}$ and Justin D. Derner ${ }^{3}$ \\ Authors are: ${ }^{1}$ Research Ecologist, USDA-ARS Rangeland Resources Research Unit, Fort Collins, CO 80523, USA; ${ }^{2}$ Research Scientist, Forest and \\ Rangeland Stewardship Department and Natural Resource Ecology Laboratory, Colorado State University, Fort Collins, CO 80523, USA; and ${ }^{3}$ Research \\ Leader and Rangeland Scientist, USDA-ARS Rangeland Resources Research Unit, Cheyenne, WY 82009, USA.
}

\begin{abstract}
Nitrogen $(\mathrm{N})$ availability can strongly influence forage quality and the capacity for semiarid rangelands to respond to increasing atmospheric $\mathrm{CO}_{2}$. Although many pathways of nitrogen input and loss from rangelands have been carefully quantified, cattlemediated $\mathrm{N}$ losses are often poorly understood. We used measurements of cattle $\mathrm{N}$ consumption rate, weight gains, and spatial distribution in shortgrass rangeland of northeastern Colorado to evaluate the influence of cattle on rangeland $\mathrm{N}$ balance. Specifically, we estimated annual rates of $\mathrm{N}$ loss via cattle weight gains and spatial redistribution of $\mathrm{N}$ into pasture corners and areas near water tanks, and used previous studies to calculate ammonia volatilization from urine patches. Using measurements of plant biomass and $\mathrm{N}$ content inside and outside grazing cages over $13 \mathrm{yr}$, we estimate that cattle stocked at 0.65 animal unit months (AUM) $\cdot \mathrm{ha}^{-1}$ consumed $3.34 \mathrm{~kg} \mathrm{~N} \cdot \mathrm{ha}^{-1} \cdot \mathrm{yr}^{-1}$. Using an independent animal-based method, we estimate that cattle consumed $3.58 \mathrm{~kg} \mathrm{~N} \cdot \mathrm{ha}^{-1} \cdot \mathrm{yr}^{-1}$ for the same stocking rate and years. A global positioning system tracking study revealed that cattle spent an average of $27 \%$ of their time in pasture corners or adjacent to water tanks, even though these areas represented only $2.5 \%$ of pasture area. Based on these measurements, we estimate that cattle stocked at $0.65 \mathrm{AUM} \cdot \mathrm{ha}^{-1}$ during the summer can remove $0.60 \mathrm{~kg} \mathrm{~N} \cdot \mathrm{ha}^{-1}$ in cattle biomass gain and spatially redistribute $0.73 \mathrm{~kg} \mathrm{~N} \cdot \mathrm{ha}^{-1}$ to areas near corners and water tanks. An additional $0.17 \mathrm{~kg} \mathrm{~N} \cdot \mathrm{ha}^{-1}$ can be lost as $\mathrm{NH}_{3}$ volatilization from urine patches. Cumulatively, these cattle-mediated pathways $\left(1.50 \mathrm{~kg} \mathrm{~N} \cdot \mathrm{ha}^{-1}\right)$ may explain the imbalance between current estimates of atmospheric inputs and trace gas losses. While $\mathrm{NO}_{\mathrm{x}}$ emission remains the largest pathway of $\mathrm{N}$ loss, spatial $\mathrm{N}$ redistribution by cattle and $\mathrm{N}$ removed in cattle biomass are the second and third largest losses, respectively. Management of cattle-mediated $\mathrm{N}$ fluxes should be recognized as one means to influence long-term sustainability of semiarid rangelands.
\end{abstract}

Key Words: grazing management, Great Plains, large herbivores, nitrogen cycling, semiarid grassland, shortgrass steppe

\section{INTRODUCTION}

Although water is the primary resource limiting plant growth in semiarid, temperate rangelands, soil nitrogen $(\mathrm{N})$ availability can strongly influence forage production and protein content (Burke et al. 1998; LeBauer and Treseder 2008), and the distribution and growth rate of large herbivores (Hyder et al. 1975; Ganskopp and Bohnert 2009). The response of semiarid rangelands to increasing atmospheric $\mathrm{CO}_{2}$ concentrations in terms of forage quantity and quality is also likely to be regulated by soil $\mathrm{N}$ availability (King et al. 2004; Milchunas et al. 2005; Reich et al. 2006; Dijkstra et al. 2010). In rangelands with low rates of atmospheric $\mathrm{N}$ deposition, understanding pathways of $\mathrm{N}$ loss or redistribution is therefore important both for contemporary management and for understanding future responses to climate change (Pineiro et al. 2010). Over the past half-century, long-term studies and syntheses have substantially advanced our understanding of soil $\mathrm{N}$ transformations and pathways of gaseous $\mathrm{N}$ loss in semiarid, temperate

\footnotetext{
Research was funded by the USDA-ARS and the Shortgrass Steppe Long Term Ecological Research Program by the National Science Foundation (NSF DEB0217631 and 0823405)

The USDA-ARS Northern Plains Area is an equal opportunity/affirmative action employer, and all agency services are available without discrimination.

Mention of trade names is for information only and does not imply an endorsement.

Correspondence: David J. Augustine, USDA-ARS, 1701 Centre Ave, Fort Collins, C0 80526, USA. Email: david.augustine@ars.usda.gov
}

Manuscript received 27 December 2011; manuscript accepted 28 August 2012.

(c) 2013 The Society for Range Management rangelands (Burke et al. 2008; Mosier et al. 2008). Because these ecosystems are characterized by low precipitation, leaching of $\mathrm{N}$ rarely occurs. Rather, $\mathrm{N}$ loss primarily occurs through gaseous emissions, with the highest loss as $\mathrm{NO}_{\mathrm{x}}$ (Table 1; Mosier et al. 2008). Lower loss rates can occur via denitrification in late winter, ammonia volatilization from aboveground vegetation, and $\mathrm{N}_{2} \mathrm{O}$ emissions (Table 1; Mosier et al. 2008).

The amount of $\mathrm{N}$ cycled through domestic livestock in these ecosystems can be significant relative to other components of the $\mathrm{N}$ cycle. Most $\mathrm{N}$ consumed by livestock is retained in the ecosystem either as dung, urine, or standing livestock biomass, but livestock can influence $\mathrm{N}$ losses via three pathways. First, $\mathrm{N}$ is removed in the form of biomass gained by livestock whenever these animals are removed from the system. Second, a portion of $\mathrm{N}$ deposited as urine is volatilized to the atmosphere. Third, livestock could spatially redistribute $\mathrm{N}$ if certain areas within pastures consistently receive greater inputs of dung and urine relative to the amount of $\mathrm{N}$ consumed there. Because large herbivores move and consume forage nonrandomly at spatial scales from individual plants to landscapes (Coughenour 1991; Bailey et al. 1996), $\mathrm{N}$ intake and excretion are often spatially uncoupled. Depending upon its magnitude, spatial redistribution of $\mathrm{N}$ could significantly influence forage production and quality in those areas of the landscape where $\mathrm{N}$ consumption consistently exceeds dung and urine deposition.

Estimates of the magnitude of these three pathways, particularly spatial redistribution, have generally been lacking in semiarid rangelands or are based on studies with limited 
Table 1. Summary of estimates of annual rates of nitrogen (N) loss from shortgrass rangeland based on studies at the Central Plains Experimental Range in northeastern Colorado.

\begin{tabular}{ccc}
\hline $\mathrm{N}$ loss pathways & $\mathrm{kg} \mathrm{N} \cdot \mathrm{ha}^{-1} \cdot \mathrm{yr}^{-1}$ & Citation \\
\hline $\mathrm{NH}_{3}$ & 0.7 & {$[1]$} \\
$\mathrm{N}_{2}$ & 0.4 & {$[2,3]$} \\
$\mathrm{NO}_{\mathrm{x}}$ & 2.2 & {$[3,4]$} \\
$\mathrm{N}_{2} \mathrm{O}$ & 0.2 & {$[3]$} \\
Total & 3.5 & - \\
\hline
\end{tabular}

'Zachariassen and Schimel 1991.

${ }^{2}$ Mosier et al. 1996, 1997.

${ }^{3}$ Mosier et al. 2008.

${ }^{4}$ Martin et al. 1998

replication. For example, a recent synthesis of $\mathrm{N}$ cycling in shortgrass rangeland had to rely on estimates of livestockmediated fluxes from $1 \mathrm{yr}$ of measurements in a single pasture (Burke et al. 2008). However, in the few cases where spatial redistribution of nutrients by livestock has been studied in detail, it has been shown to substantially influence rangeland $\mathrm{N}$ balance and nutrient heterogeneity (Augustine 2003; Schnyder et al. 2010; Van Uytvanck et al. 2010). Our objective was to quantify the influence of cattle on $\mathrm{N}$ balance in shortgrass rangeland. We integrate measurements from 1) long-term studies of forage production, consumption and $\mathrm{N}$ content, 2) a study of cattle spatial distribution, and 3) previously published research on $\mathrm{N}$ cycling and cattle $\mathrm{N}$ intake rates, in order to estimate the magnitude of each of the three pathways by which cattle influence $\mathrm{N}$ loss (weight gain, $\mathrm{N}$ volatilization, and $\mathrm{N}$ redistribution). To assess spatial redistribution of $\mathrm{N}$, we examined cattle distribution relative to pasture corners and water sources, as these areas are often disproportionately used during nonforaging (loafing, bedding) periods (Senft 1983; White et al. 2001), and hence can receive disproportionate inputs of $\mathrm{N}$ as dung and urine. We then compare our estimates of cattle-mediated $\mathrm{N}$ fluxes with estimates of atmospheric $\mathrm{N}$ inputs and pathways of $\mathrm{N}$ loss that are not influenced by cattle (Burke et al. 2008; Mosier et al. 2008).

\section{METHODS}

\section{Study Area}

All measurements were conducted at the USDA-ARS Central Plains Experimental Range (CPER) located approximately 40 $\mathrm{km}$ northeast of Nunn, Colorado (lat $40^{\circ} 50^{\prime} \mathrm{N}$, long $\left.104^{\circ} 43^{\prime} \mathrm{W}\right)$. Mean annual precipitation is $340 \mathrm{~mm}$, and growing season precipitation (May-September) is $243 \mathrm{~mm}$. During the growing season, potential evapotranspiration is approximately three times greater than precipitation (Lauenroth and Bradford 2006). Topography is characterized by gently undulating plains. Blue grama (Bouteloua gracilis [Willd. Ex Kunth] Lag. ex Steud) and buffalograss (Buchloe dactyloides [Nutt.] J. T. Columbus) are the dominant grasses $(>80 \%$ of ANPP), and scarlet globemallow (Sphaeralcea coccinia [Nutt] Rydb.) is the most abundant forb; mean annual aboveground plant production is $\sim 100 \mathrm{~g} \cdot \mathrm{m}^{-2}$ (Lauenroth and Milchunas 1992).

\section{Plant-Based Estimate of Annual N Consumption by Cattle}

We measured aboveground herbaceous biomass each year during 1992-2004 in six pastures. In each pasture, we harvested aboveground herbaceous biomass in early August of each year in four $0.25-\mathrm{m}^{2}$ quadrats located inside temporary, moveable $1-\mathrm{m}^{2}$ exclosures that prevented cattle grazing, and four $0.25-\mathrm{m}^{2}$ quadrats outside cages. Biomass harvest locations did not occur near water sources or pasture corners. Biomass was sorted into current-year production of each species, ovendried, and weighed. Biomass harvests in early August best estimate peak standing crop in this dominantly warm-season community, and provide similar estimates of aboveground net primary production (ANPP) as more rigorous ${ }^{14} \mathrm{C}$ turnover methods (Milchunas and Lauenroth 1992). For each quadrat, biomass of $B$. gracilis and $B$. dactyloides were combined, ground in a Wiley mill, and analyzed for $\mathrm{N}$ content using a carbon and nitrogen analyzer (LECO Corporation, St. Joseph, MI). Similarly, biomass of all other species was combined, ground, and analyzed for $\mathrm{N}$ content. $\mathrm{N}$ mass was calculated for each functional group in each quadrat, and summed to obtained $\mathrm{N}$ mass per quadrat. $\mathrm{N}$ consumption was calculated as the difference in mean herbaceous $\mathrm{N}$ mass of ungrazed quadrats vs. grazed quadrats for each of the six pastures. We used replication at the pasture level to derive an estimate of the mean and variance in $\mathrm{N}$ consumption as of the date of the biomass harvest for each year.

Our estimate of $\mathrm{N}$ consumption was based on August plant biomass sampling, but plant $\mathrm{N}$ content and intake by cattle is highest in June (Senft 1983), and typically declines from June until November due aging of plant tissues and $\mathrm{N}$ translocation belowground. Thus, the early August plant measurements could underestimate $\mathrm{N}$ consumption during June through August but overestimate $\mathrm{N}$ consumption during August through October. We therefore evaluated monthly variation in plant $\mathrm{N}$ content by collecting monthly samples of the dominant grass (B. gracilis) and the dominant forb (S. coccinea) during May through October for 5 yr (1995-1999) and analyzing them for $\mathrm{N}$ content. We also evaluated monthly patterns of $\mathrm{N}$ intake measured by Senft (1983) using cannulated yearling heifers. We compared plant $\mathrm{N}$ content and cattle $\mathrm{N}$ intake rate averaged over the six monthly measurements to the August point estimate to test whether our $\mathrm{N}$ consumption rate estimate based on the August plant sampling may significantly over- or underestimate $\mathrm{N}$ consumption.

Stocking rates in the six pastures where we conducted plant measurements varied annually in response to the precipitation. Cattle entered the pastures in mid-May each year and remained until October if forage conditions were sufficient, but were removed earlier in years with low plant production. Animal type varied among years and pastures and included yearling steers, yearling heifers and second-year heifers. During 19922004, the six pastures were stocked at an average rate of 0.65 AUM $\cdot \mathrm{ha}^{-1}$. We corrected for $\mathrm{N}$ consumption by cattle after the date of our plant biomass measurements based on how long cattle remained in pastures each year. Cattle were weighed at 
the beginning and end of the grazing season, and stocking rate was calculated based on animal metabolic weight.

\section{Animal-Based Estimate of Annual N Consumption}

Senft (1983) measured monthly rates of $\mathrm{N}$ intake by cannulated yearling heifers during 1980-1981 at CPER, and expressed them on a metabolic body weight basis. During 1992-2004, one pasture at CPER was stocked annually with yearling heifers at $0.51 \mathrm{AUM} \cdot \mathrm{ha}^{-1}$, and these animals were weighed at $1-\mathrm{mo}$ intervals during the grazing season. We used these monthly body weights combined with Senft's (1983) monthly estimates of $\mathrm{N}$ intake to calculate the annual amounts of $\mathrm{N}$ consumed in this pasture, and also used the net change in body weight over the grazing season to calculate $\mathrm{N}$ removal in weight gain. Because the pasture was stocked at a lower rate $(0.51$ AUM $\cdot \mathrm{ha}^{-1}$ ) than the six pastures where we measured plant biomass and $\mathrm{N}$ content $\left(0.65 \mathrm{AUM} \cdot \mathrm{ha}^{-1}\right)$, we assumed $\mathrm{N}$ intake would increase in direct proportion to an increase in stocking rate, and expressed all of our $\mathrm{N}$ cycling calculations in terms of a stocking rate of $0.65 \mathrm{AUM} \cdot \mathrm{ha}^{-1}$. Plant-based estimates of $\mathrm{N}$ consumption were not available for the pasture with monthly heifer body weights.

\section{Spatial Partitioning of N Intake and N Excretion}

Previous analyses of cattle spatial distribution in shortgrass rangeland were limited to a single 130-ha pasture studied during 1980-1981 at CPER (Senft 1983). This study documented strong disproportionate use of areas near fence corners and water tanks for nongrazing activities (travelling, standing, resting, and bedding). Differential use of these small portions of the pasture for nongrazing activities was the primary factor driving spatial redistribution of $\mathrm{N}$ by cattle (Senft 1983).

Advances in systems to track large herbivores using global positioning system (GPS) units (e.g., Ungar et al. 2005) provided an opportunity to more precisely quantify cattle spatial distribution in pastures. In 2008, we quantified the spatial distribution of yearling steers in five pastures at CPER using Lotek GPS3300 collars (Lotek Engineering, Newmarket, ON, Canada). Collars were programmed to record GPS fixes at 5-min intervals, and were deployed during four time periods: 1) 15 May-4 June, 2) 13 June-2 July, 3) 11 July-31 July, and 4) 8 August-2 September. During the first and third interval, we deployed collars on three steers in each of two 130-ha pastures (six steers total). During the second and fourth interval, we deployed collars on three steers in each of three 65-ha pastures (nine steers total). Data were imported into a geographic information system (ArcGIS version 9.1). For each steer and time interval, we calculated the proportion of fixes that occurred within $50 \mathrm{~m}$ of pasture fence corners, within $100 \mathrm{~m}$ of water tanks located in a pasture corner, or within $75 \mathrm{~m}$ of water tanks not located in a pasture corner. We used the larger radius for water tanks located in corners due to the more restricted area available to the cattle when accessing water in corners compared to pastures with the tank located away from the fence.

\section{Calculation of a Spatial N Budget for Shortgrass Rangeland}

The amount of $\mathrm{N}$ removed from pastures in cattle biomass was estimated using two different datasets on cattle weight gains. First, for the six pastures where we sampled vegetation to estimate $\mathrm{N}$ consumption rates, cattle were weighed at the beginning and end of the grazing season. The net change in cattle biomass was used to calculate $\mathrm{N}$ removal assuming $2.72 \% \mathrm{~N}$ in that biomass (Dean et al. 1975). This estimate was used to develop an $\mathrm{N}$ budget in association with the plantbased estimate of $\mathrm{N}$ consumption. Second, for the pasture where we used monthly measurements of cattle weights to derive the animal-based estimate of $\mathrm{N}$ consumption, we used the net weight gain over each grazing season to calculate $\mathrm{N}$ removed in cattle biomass, again assuming $2.72 \% \mathrm{~N}$ in that biomass. Stocking rate in this pasture during 1992-2004 was $0.51 \mathrm{AUM} \cdot \mathrm{ha}^{-1}$, so the $\mathrm{N}$ removal estimate was extrapolated to a stocking rate of $0.65 \mathrm{AUM} \cdot \mathrm{ha}^{-1}$, and used to develop an $\mathrm{N}$ budget in combination with the animal-based estimate of $\mathrm{N}$ consumption.

Based on our cattle distribution study, we developed $\mathrm{N}$ budgets for shortgrass rangeland excluding that portion of the pasture within $50 \mathrm{~m}$ of corners, $75 \mathrm{~m}$ of tanks in corners, and $75 \mathrm{~m}$ of tanks away from corners. $\mathrm{N}$ budgets assume $2.5 \%$ of the pasture is near tanks and corners. Many previous studies of livestock $\mathrm{N}$ excretion in relation to grazing, travelling, resting, and other activities have demonstrated that dung and urine deposition is directly related to time spent by an animal in an area, regardless of activity (Lange and Willcocks 1979; Senft 1983; White et al. 2001; Auerswald et al. 2010; Van Uytvanck et al. 2010; Moir et al. 2011). Based on these studies, we assumed that cattle intake of forage $\mathrm{N}$ in a given area was proportional to the percent of the pasture that the area occupied, while excretion of $\mathrm{N}$ in dung and urine in an area was proportional to the amount of time cattle spent there.

Cattle also influence $\mathrm{N}$ loss via volatilization from urine patches. Volatilization rates depend on soil texture, humidity, temperature, and activity of plants and microbes (Schimel et al. 1986; Milchunas et al. 1988). Based on studies of urea-N volatilization at CPER during the growing season, we assumed that $14 \%$ of $\mathrm{N}$ is volatilized from urine patches (Schimel et al. 1986; Milchunas et al. 1988). Senft (1983) estimated that 53\% of $\mathrm{N}$ excreted by cattle during May through October is as urine. We therefore calculated $\mathrm{N}$ volatilization from urine patches for the $97.5 \%$ of the pasture away from corners and water tanks as ([ $\mathrm{N}$ consumption $-\mathrm{N}$ removed in cattle weight gain $-\mathrm{N}$ redistributed to tanks and corners] $\times 0.53 \times 0.14$ ).

Finally, we compared cattle-mediated $\mathrm{N}$ fluxes with $\mathrm{N}$ inputs to the ecosystem via atmospheric deposition, and $\mathrm{N}$ losses via $\mathrm{NO}_{\mathrm{x}}, \mathrm{N}_{2}, \mathrm{~N}_{2} \mathrm{O}$, and $\mathrm{NH}_{3}$ fluxes from the soil and plants. Net pasture $\mathrm{N}$ balance was calculated as the difference between all inputs and losses. We compared net pasture $\mathrm{N}$ balance for the two different methods of estimating $\mathrm{N}$ consumption for cattle based for an adjusted equivalent stocking rate of 0.65 $\mathrm{AUM} \cdot \mathrm{ha}^{-1}$.

\section{RESULTS}

\section{Plant-Based Estimates of $\mathrm{N}$ Intake}

Nitrogen content of B. gracilis and S. coccinia was greatest during May through June and then declined monotonically over the grazing season. Nitrogen content of $B$. gracilis collected in August $(\mathrm{X} \pm 1 \mathrm{SE}=1.34+0.09 \%)$ was similar to $\mathrm{N}$ content averaged over all 6 mo of sampling $(1.28+0.08 \%$; 


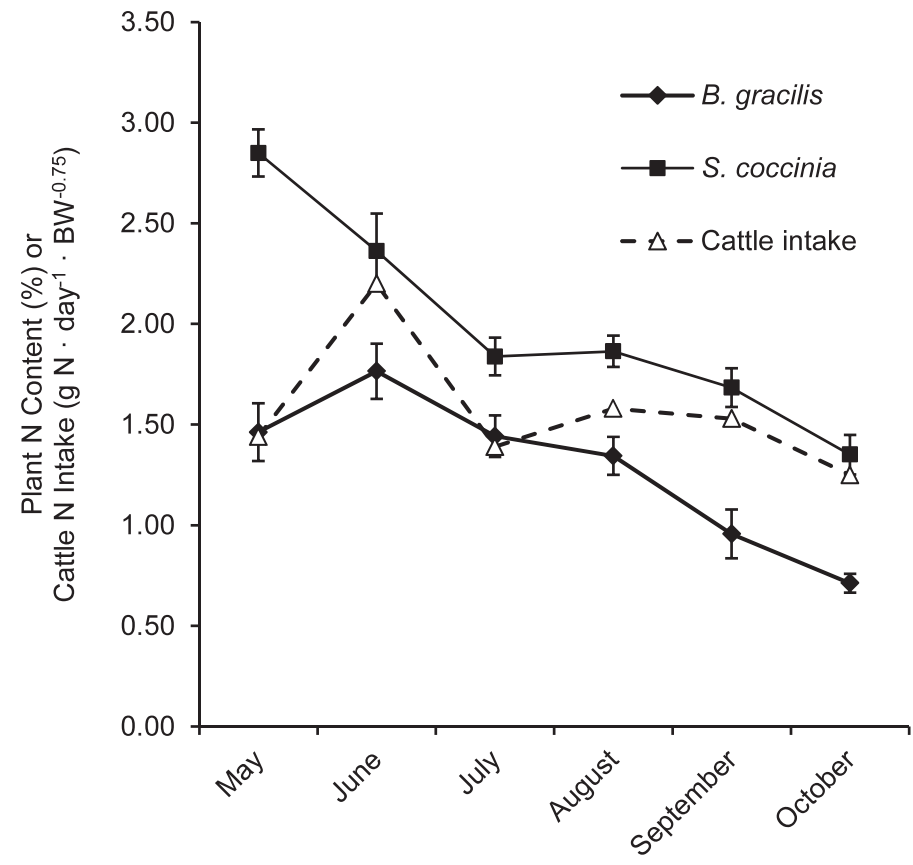

Figure 1. Seasonal variation in N content of aboveground biomass of the dominant grass (Bouteloua gracilis) and the dominant forb (Sphaeralcea coccinia) sampled annually during 1995-1999 in shortgrass rangeland at the Central Plains Experimental Range in northeastern Colorado. Monthly estimates of cattle N intakes reported by Senft (1983) are also shown for comparison.

paired $t=1.17, P=0.31$; Fig. 1$)$. Nitrogen content of $S$. coccinia in August $(1.86+0.08 \%)$ was slightly lower than $\mathrm{N}$ content averaged over all 6 mo of sampling $(1.99+0.07 \%$; paired $t=3.23, P=0.032$ ), but the magnitude of this difference $(0.13 \% \mathrm{~N})$ was small relative to seasonal variation (from $2.85 \%$ in May to $1.35 \%$ in October; Fig. 1). Based on cattle N intake rates measured monthly by Senft (1983), August N intake $\left(1.58 \mathrm{~g} \mathrm{~N} \cdot \mathrm{d}^{-1} \cdot\right.$ body weight $\left.{ }^{-0.75}\right)$ was nearly identical to $\mathrm{N}$ intake averaged over the 6 monthly estimates for May through October $\left(1.57 \mathrm{~g} \mathrm{~N} \cdot \mathrm{day}^{-1}\right.$. body weight $\left.{ }^{-0.75}\right)$. Based on these findings, we assumed that the daily $\mathrm{N}$ intake rate estimated from August sampling of plant biomass could be directly extrapolated to estimate $\mathrm{N}$ intake rate for the full May through October grazing season based on the total number of grazing days in a given year.

Aboveground mass of $\mathrm{N}$ in vegetation at peak standing crop averaged $11 \mathrm{~kg} \mathrm{~N} \cdot \mathrm{ha}^{-1}$ over the 13 -yr period, varying from 5.0 $\mathrm{kg} \cdot \mathrm{ha}^{-1}$ for a severe drought in 2002 to $20.5 \mathrm{~kg} \cdot \mathrm{ha}^{-1}$ for a wet year in 1999 (Table 1). Daily $\mathrm{N}$ consumption measured as the difference between $\mathrm{N}$ yield in ungrazed vs. grazed quadrats harvested in August in pastures with a mean stocking rate of $0.65 \mathrm{AUM} \cdot \mathrm{ha}^{-1}$ averaged $0.024 \mathrm{~kg} \cdot \mathrm{ha}^{-1} \cdot \mathrm{d}^{-1}$, which translates to a mean $\mathrm{N}$ consumption rate of $3.58 \mathrm{~kg} \mathrm{~N} \cdot \mathrm{ha}^{-1}$ for the full grazing season. Linear extrapolation to a heavy stocking rate of $1.0 \mathrm{AUM} \cdot \mathrm{ha}^{-1}$ gives an annual $\mathrm{N}$ consumption rate of $5.51 \mathrm{~kg} \mathrm{~N} \cdot \mathrm{ha}^{-1}$.

\section{Animal-Based Estimates of $\mathrm{N}$ Intake}

For the pasture where yearling heifers were weighed monthly during 1992-2004, cattle entered in mid-May (range of 12-22
May) at a mean body mass of $284.0 \mathrm{~kg}$. In most years, cattle grazed until early October (range 2-16 October), but they were removed earlier during drought years (12 August in 1994, 11 August in 2000, and 8 August in 2002), with a mean grazing season of $130 \mathrm{~d}$. Across years, mean weight at the end of the grazing season was $387 \mathrm{~kg}$, and mean annual stocking rate for this pasture was $0.51 \mathrm{AUM} \cdot \mathrm{ha}^{-1}$. Monthly body weights were multiplied by the number of grazing days in the month and monthly $\mathrm{N}$ intake rate reported by Senft (1983), and products were summed across all months in the grazing season to give annual $\mathrm{N}$ consumption estimates varying from 1.61 to 2.98 $\mathrm{kg} \cdot \mathrm{ha}^{-1} \cdot \mathrm{yr}^{-1}$. Because the stocking rate $\left(0.51 \mathrm{AUM} \cdot \mathrm{ha}^{-1}\right)$ was lower than for pastures where we measured $\mathrm{N}$ consumption with grazing cages $\left(0.65 \mathrm{AUM} \cdot \mathrm{ha}^{-1}\right)$, the animal-based estimates were adjusted assuming a linear increase in $\mathrm{N}$ intake with stocking rate, giving estimates varying from 2.06 to 3.80 $\mathrm{kg} \cdot \mathrm{ha}^{-1} \cdot \mathrm{yr}^{-1}$, and a 13 -yr mean of $3.34 \mathrm{~kg} \cdot \mathrm{ha}^{-1} \cdot \mathrm{yr}^{-1}$ (Table 2). This estimate is similar to the plant-based estimates for the same series of years (paired $t$-test, $N=13, t=0.679, P=0.51$ ).

\section{Cattle Spatial Distribution}

The GPS tracking study revealed that cattle spent an average of $27 \%$ of their time in pasture corners or near water tanks (Table 3 ), which comprised only $2.5 \%$ of the area in pastures (Table $3)$. Cattle spent an average of $73 \%$ of their time in the remaining $97.5 \%$ of the pastures. The ratio of time spent near corners and water to area occupied by them was greatest in pasture 2 , where steers spent $36.5 \%$ of their time in $1.1 \%$ of the pasture, and least in pasture 5 , where steers spent $20 \%$ of their time in $3.9 \%$ of the pasture. Based on these results, the amount of $\mathrm{N}$ removed from the portion of the pasture away from tanks and corners (and hence redistributed into areas near corners and tanks) was estimated as $24.5 \%$ of the total $\mathrm{N}$ excreted by cattle, i.e., $24.5 \%$ of the difference between $\mathrm{N}$ consumption and $\mathrm{N}$ removed in cattle weight gains.

\section{Spatial N Budget for Shortgrass Rangeland}

$\mathrm{N}$ budgets for the both the plant and animal-based estimates of $\mathrm{N}$ consumption and $\mathrm{N}$ removal in cattle weight gains were strikingly similar (Table 4). Both approaches indicate that $\mathrm{N}$ inputs and losses are balanced for moderately stocked shortgrass rangeland. Cattle-mediated $\mathrm{N}$ losses were cumulatively $1.39-1.50 \mathrm{~kg} \cdot \mathrm{ha}^{-1}$, or $28-30 \%$ of current estimates of atmospheric $\mathrm{N}$ inputs as reported by Burke et al. (2008). N spatially redistributed to corners and water tanks $(0.68-0.73$ $\mathrm{kg} \cdot \mathrm{ha}^{-1}$ ) was the largest cattle-mediated loss pathway (Table 4).

\section{DISCUSSION}

Over the past half-century, internal cycling and net balance of $\mathrm{N}$ in shortgrass rangeland has been intensively studied (Clark 1977; Hook and Burke 2000; Burke et al. 2008). Annual N inputs from atmospheric deposition are estimated to be $\sim 5.0$ $\mathrm{kg} \mathrm{N} \cdot \mathrm{ha}^{-1}$ (Holland et al. 1999; Burke et al. 2008), while $\mathrm{N}$ gas losses $\left(\mathrm{NO}_{\mathrm{x}}, \mathrm{N}_{2} \mathrm{O}, \mathrm{N}_{2}\right.$, and plant-emitted $\left.\mathrm{NH}_{3}\right)$ are estimated to be $\sim 3.5 \mathrm{~kg} \cdot \mathrm{ha}^{-1}$ (Table 1; Mosier et al. 2008). Because leaching and $\mathrm{N}_{2}$-fixation are both negligible in this 
Table 2. Estimates of nitrogen (N) consumption by cattle at the Central Plains Experimental Range (CPER) in northeastern Colorado during 1992-2004 using plant-based vs. animal-based methods, based on a stocking rate of 0.65 Animal Unit Months (AUM) $\cdot$ ha $^{-1}$. The plant-based method uses measurements of $\mathrm{N}$ in aboveground herbaceous plant biomass inside vs. outside temporary grazing cages in six pastures for the 13-yr study period. The animal-based method is derived from weights of yearling heifers measured monthly in one pasture at the CPER during 1992-2004, multiplied by monthly estimates of $\mathrm{N}$ intake $\left(\mathrm{g} \mathrm{N}\right.$. bodyweight ${ }^{-0.75} \cdot \mathrm{d}^{-1}$ ) reported by Senft (1983; Fig. 1). Annual standard errors are based on variation among the six pastures within a given year; standard errors for the 13-yr means are based on among-year variation.

\begin{tabular}{|c|c|c|c|c|c|c|c|}
\hline \multirow[b]{2}{*}{ Year } & \multicolumn{2}{|c|}{$\begin{array}{l}\mathrm{N} \text { in peak standing crop } \\
\left(\mathrm{kg} \mathrm{N} \cdot \mathrm{ha}^{-1}\right)\end{array}$} & \multicolumn{2}{|c|}{$\begin{array}{l}\text { Plant-based mean daily } \mathrm{N} \\
\text { consumption rate } \\
\left(\mathrm{kg} \mathrm{N} \cdot \mathrm{ha}^{-1} \cdot \mathrm{d}^{-1}\right) \\
\text { for } 0.65 \mathrm{AUM} \cdot \mathrm{ha}^{-1}\end{array}$} & \multicolumn{2}{|c|}{$\begin{array}{c}\text { Plant-based annual N } \\
\text { consumption }\left(\mathrm{kg} \mathrm{N} \cdot \mathrm{ha}^{-1} \cdot \mathrm{yr}^{-1}\right) \\
\text { for } 0.65 \mathrm{AUM} \cdot \mathrm{ha}^{-1}\end{array}$} & \multirow{2}{*}{$\begin{array}{l}\begin{array}{c}\text { Animal-based annual } \\
\mathrm{N} \text { consumption }\end{array} \\
\left(\mathrm{kg} \mathrm{N} \cdot \mathrm{ha}^{-1} \cdot \mathrm{yr}^{-1}\right) \\
\frac{\text { for } 0.65 \mathrm{AUM} \cdot \mathrm{ha}^{-1}}{\text { Mean }}\end{array}$} \\
\hline & Mean & $1 \mathrm{SE}$ & Mean & $1 \mathrm{SE}$ & Mean & $1 \mathrm{SE}$ & \\
\hline 1992 & 14.88 & 1.84 & 0.020 & 0.007 & 2.91 & 1.01 & 3.78 \\
\hline 1993 & 6.50 & 0.79 & 0.019 & 0.010 & 3.03 & 1.51 & 3.60 \\
\hline 1994 & 8.85 & 0.83 & 0.007 & 0.010 & 0.98 & 1.45 & 2.19 \\
\hline 1995 & 13.95 & 2.12 & 0.034 & 0.010 & 5.31 & 1.54 & 3.80 \\
\hline 1996 & 9.67 & 2.14 & 0.027 & 0.007 & 4.45 & 1.22 & 3.63 \\
\hline 1997 & 14.89 & 0.91 & 0.036 & 0.012 & 5.83 & 1.88 & 3.63 \\
\hline 1998 & 12.05 & 1.98 & 0.024 & 0.019 & 3.91 & 3.08 & 3.69 \\
\hline 1999 & 20.54 & 2.58 & 0.041 & 0.021 & 5.88 & 3.03 & 3.70 \\
\hline 2000 & 6.09 & 1.28 & 0.032 & 0.015 & 3.59 & 1.72 & 2.13 \\
\hline 2001 & 11.94 & 1.06 & 0.023 & 0.016 & 3.36 & 2.37 & 3.78 \\
\hline 2002 & 5.04 & 0.69 & 0.018 & 0.003 & 1.85 & 0.33 & 2.06 \\
\hline 2003 & 11.28 & 0.82 & 0.023 & 0.016 & 3.34 & 2.38 & 3.74 \\
\hline 2004 & 8.23 & 1.02 & 0.015 & 0.008 & 2.16 & 1.10 & 3.73 \\
\hline $13-y r$ & 11.07 & 1.02 & 0.024 & 0.003 & 3.58 & 0.41 & 3.34 \\
\hline
\end{tabular}

system, it remains unclear how the imbalance between inputs and losses can be explained (Burke et al. 2008). Recent syntheses of trace gas flux (Mosier et al. 2008) and shortgrass N cycling (Burke et al. 2008) relied on studies by Senft (1983), Senft et al. (1985), and Schimel et al. (1986) to suggest that cattle effects on $\mathrm{N}$ cycling were small relative to cumulative trace gas fluxes.

Our analysis using a plant-based method (moveable grazing cages) that was independent of the studies by Senft (1983) replicated across six moderately stocked pastures, and repeated for $13 \mathrm{yr}$ estimated annual consumption of $\mathrm{N}$ by cattle to be $3.58 \mathrm{~kg} \mathrm{~N} \cdot \mathrm{ha}^{-1}$. This represents $32 \%$ of $\mathrm{N}$ in peak annual standing herbaceous biomass $\left(11.07 \mathrm{~kg} \mathrm{~N} \cdot \mathrm{ha}^{-1}\right)$. Given that $\mathrm{N}$ consumed by cattle is either 1) removed in cattle biomass, 2) deposited as dung and urine near corners or water tanks, or 3) returned to the rangeland as dung and urine (a form that is substantially altered compared to plant litter in its availability to microbes and plants), it is clear from this estimate alone that cattle can have a substantial influence on the $\mathrm{N}$ cycle.
Furthermore, using replicated measurements of cattle weight gains in six pastures over $13 \mathrm{yrs}$, and replicated measurements of cattle distribution in five pastures over $1 \mathrm{yr}$, we find that cattle stocked at $0.65 \mathrm{AUM} \cdot \mathrm{ha}^{-1}$ can remove $0.60 \mathrm{~kg} \mathrm{~N} \cdot \mathrm{ha}^{-1}$ in cattle biomass gain and spatially redistribute $0.73 \mathrm{~kg} \mathrm{~N} \cdot \mathrm{ha}^{-1}$ to corners and watering areas. Of the $\mathrm{N}$ returned to the bulk of the pasture as dung and urine (estimated by difference as 2.08 $\mathrm{kg} \mathrm{N} \cdot \mathrm{ha}^{-1}$ ), an additional $0.17 \mathrm{~kg} \mathrm{~N} \cdot \mathrm{ha}^{-1}$ can be lost as $\mathrm{NH}_{3}$ volatilization. Cumulatively, these cattle-mediated pathways $\left(1.50 \mathrm{~kg} \mathrm{~N} \cdot \mathrm{ha}^{-1}\right)$ can explain the imbalance between atmospheric inputs and trace gas losses. While $\mathrm{NO}_{\mathrm{x}}$ remains the largest pathway of $\mathrm{N}$ loss, spatial $\mathrm{N}$ redistribution by cattle and $\mathrm{N}$ removed in cattle biomass are the second and third largest losses, respectively.

How can we reconcile our findings with previous reviews on shortgrass $\mathrm{N}$ cycling that suggested a minimal influence of cattle? Examination of the methods and assumptions inherent in $\mathrm{N}$ flux rates reported by Senft (1983) and Schimel et al. (1986) indicate it can be explained on the basis of assumptions

Table 3. Amount of time spent by steers within $50 \mathrm{~m}$ of pasture corners, $100 \mathrm{~m}$ of water tanks in corners, and $75 \mathrm{~m}$ of water tanks away from corners for five pastures at the Central Plains Experimental Range in northeastern Colorado in 2008. Numbers in parentheses show standard errors based on three steers tracked using global positioning system (GPS) collars in each pasture.

\begin{tabular}{lccccc}
\hline \multicolumn{1}{c}{ Pasture } & Size (ha) & Dates sampled & GPS fixes - steer $^{-1}$ & \% Time near water and corners & \% of Pasture (Area) \\
\hline 1 & 130 & 15 May-4 June; 11 July-31 July & 11808 & $25.5(0.9)$ & 1.1 \\
2 & 130 & 15 May-4 June; 11 July-31 July & 11807 & $36.5(0.4)$ & $31.3(0.8)$ \\
3 & 65 & 13 June-2 July; 8 August-2 September & 12672 & $21.8(0.5)$ & 3.9 \\
4 & 65 & 13 June-2 July; 8 August-2 September & 12671 & $20.0(0.4)$ & 2.6 \\
5 & 65 & 13 June-2 July; 8 August-2 September & 12938 & $27.0(3.1)$ & 2.9 \\
5-pasture Mean & & - & 12379 & & $2.5(0.6)$ \\
\hline
\end{tabular}


Table 4. Comparison of estimates of cattle-mediated nitrogen (N) fluxes with $\mathrm{N}$ inputs and losses not influenced by cattle for the Central Plains Experimental Range in northeastern Colorado. Animal vs. plant-based estimates of $\mathrm{N}$ consumption by cattle were calculated using two independent methods for the period 1992-2004 (Table 2), based on a stocking rate of 0.65 Animal Unit Months (AUM) $\cdot \mathrm{ha}^{-1} \mathrm{~N}$ removed in weight gains was estimated based on measured cattle weight gains for 1992-2004 assuming 2.72\% N in cattle biomass (Dean et al. 1975). N redistribution by cattle (to areas near pasture corners and water tanks) and $\mathrm{NH}_{3}$ volatilization from urine patches were calculated as a proportion of the $\mathrm{N}$ consumption estimate based on cattle distribution analyses (global positioning system [GPS] telemetry) and previous measures of $\mathrm{N}$ volatilization (Schimel et al. 1986; Milchunas et al. 1988).

\begin{tabular}{|c|c|c|c|}
\hline & $\begin{array}{l}\text { Nonlivestock } \\
\text { N fluxes }\end{array}$ & $\begin{array}{c}\text { Animal-based } \\
\text { estimates for } \\
0.65 \mathrm{AUM} \cdot \mathrm{ha}^{-1}\end{array}$ & $\begin{array}{c}\text { Plant-based } \\
\text { estimates for } \\
0.65 \mathrm{AUM} \cdot \mathrm{ha}^{-1}\end{array}$ \\
\hline \multicolumn{4}{|l|}{ Inputs: } \\
\hline Wet deposition & $2.5^{1}$ & - & - \\
\hline Dry deposition & $2.5^{1}$ & - & - \\
\hline \multicolumn{4}{|l|}{ Internal: } \\
\hline $\mathrm{N}$ consumption by cattle & - & 3.34 & 3.58 \\
\hline $\mathrm{N}$ deposition by cattle & - & 1.95 & 2.08 \\
\hline \multicolumn{4}{|l|}{ Losses: } \\
\hline $\begin{array}{l}\mathrm{N}_{2} \mathrm{O}, \mathrm{N}_{2}, \mathrm{NO}_{x} \text { and plant- } \mathrm{NH}_{3} \\
\quad \text { loss }\end{array}$ & $\begin{array}{c}3.5 \\
\text { (Table 1) }\end{array}$ & - & - \\
\hline $\begin{array}{l}\mathrm{N} \text { removed in cattle } \\
\text { biomass }\end{array}$ & - & 0.55 & 0.60 \\
\hline $\begin{array}{l}\mathrm{N} \text { redistributed to tanks and } \\
\text { corners }\end{array}$ & - & 0.68 & 0.73 \\
\hline $\begin{array}{l}\mathrm{NH}_{3} \text { Volatilization from urine } \\
\text { patches }\end{array}$ & - & 0.16 & 0.17 \\
\hline $\begin{array}{l}\text { Net pasture } \mathrm{N} \text { balance } \\
\text { excluding tanks and } \\
\text { corners }\end{array}$ & - & 0.11 & 0.00 \\
\hline $\begin{array}{l}\text { Net cattle } \mathrm{N} \text { deposition at } \\
\text { tanks and corners }\end{array}$ & - & 26.7 & 28.5 \\
\hline
\end{tabular}

${ }^{1}$ Burke et al. 2008.

concerning stocking density and the season of grazing. Senft (1983) measured $\mathrm{N}$ intake by cattle in a pasture with a relatively low stock density (10 yearling heifers in $126 \mathrm{ha}$ ) year round; estimates presented by Schimel et al. (1986) are based on the same scenario. In contrast, most upland shortgrass rangeland in this region, including nearly all publicly managed rangeland, have at least twice that stock density during the summer (May through October) grazing season, but no winter grazing. Summer cattle grazing has much greater effects on $\mathrm{N}$ cycling than does dormant season grazing, because $\mathrm{N}$ intake rates are greatest during June through August (Fig. 1). When we applied $\mathrm{N}$ intake rates measured by Senft (1983) on a per heifer basis during May through October to monthly heifer weights measured at our study site during 1992-2004, we estimate a mean annual $\mathrm{N}$ intake rate of $3.34 \mathrm{~kg} \mathrm{~N} \cdot \mathrm{ha}^{-1}$, which is similar to our plant-based estimates for the same series of years (Table 2). Given that the plant-based and animal-based estimates were derived from independent data, their congruence gives us confidence that summer grazing by cattle at 0.65
AUM $\cdot \mathrm{ha}^{-1}$ has a substantial effect on the $\mathrm{N}$ cycle, and influences overall $\mathrm{N}$ balance, in the landscape we studied.

The precision of $\mathrm{N}$ flux estimates for semiarid rangelands is low because most fluxes are relatively small (on an annual basis) and strongly influenced by temporal and spatial variability. Precision of our cattle $\mathrm{N}$ redistribution estimate depends on variation in 1) the annual $\mathrm{N}$ consumption by cattle, and 2) the proportion of time cattle spend in corner/tank areas minus the proportion of the pasture area comprising these $\mathrm{N}$ sink areas. For the former, the $95 \%$ confidence interval for the plant-based method was $2.68-4.48 \mathrm{~kg} \cdot \mathrm{ha}^{-1}$; for the latter, the five pastures we measured ranged from 16.1 to 35.5. Using the lowest and the highest estimates of both parameters gives a range of $0.33-1.38 \mathrm{~kg} \mathrm{~N} \cdot \mathrm{ha}^{-1}$ lost via redistribution by cattle at $0.65 \mathrm{AUM} \cdot \mathrm{ha}^{-1}$. A similar range cannot be calculated for the animal-based estimate because error was not reported for the monthly heifer $\mathrm{N}$ intake estimates (Senft 1983), but the $0.68 \mathrm{~kg} \mathrm{~N} \cdot \mathrm{ha}^{-1}$ estimate corresponds very closely to the mean plant-based estimate $\left(0.73 \mathrm{~kg} \mathrm{~N} \cdot \mathrm{ha}^{-1}\right)$. Cattle redistribution is thus likely to be the most important loss pathway other than $\mathrm{NO}_{\mathrm{x}}$ emissions (Tables 1 and 3).

Regarding our urine- $\mathrm{N}$ volatilization estimate, Schimel et al. (1986) found $27 \%$ of $\mathrm{N}$ was volatilized from urine patches in uplands and $0 \%$ in lowlands during the growing season. Milchunas et al. (1988) found $14.1 \% \mathrm{~N}$ lost from urine patches on a backslope, and $1.5 \% \mathrm{~N}$ loss in a lowland during the growing season. Based on the assumption of $70 \%$ upland and $30 \%$ swales in a typical shortgrass pasture, the weighted average percent $\mathrm{N}$ loss is $10.3 \%$ (Milchunas et al. 1988) to $18.9 \%$ (Schimel et al. 1986), with a mean of $14.6 \%$. Even substantial variation in this estimate of percent loss (e.g., from $10 \%$ to $20 \%$ of urine- $\mathrm{N}$ volatilized, equivalent to $0.11-0.22 \mathrm{~kg}$ $\mathrm{N} \cdot \mathrm{ha}^{-1}$ lost) has a minor influence on our total estimate of cattle effect on $\mathrm{N}$ losses.

Estimates of atmospheric $\mathrm{N}$ inputs via dry deposition and $\mathrm{NH}_{3}$ volatilization from plants have high uncertainty (Burke et al. 2008). We suggest that cattle-mediated loss estimates presented here combined with improved estimates of dry deposition, and $\mathrm{NH}_{3}$ flux from grazed grass canopies (excluding urine-affected patches) will be most important to assessing $\mathrm{N}$ balance of shortgrass rangelands. Because the magnitude of all cattle-mediated $\mathrm{N}$ fluxes depend upon $\mathrm{N}$ consumed per unit area, these fluxes will vary in response to regional gradients in forage production (Lauenroth et al. 1999) and stocking rates in the shortgrass steppe.

\section{MANAGEMENT IMPLICATIONS}

Pasture design (distribution of fences and water sources) could have an important influence on $\mathrm{N}$ redistribution by cattle. Our measurements only apply to small (65-130 ha) pastures. Variation in pasture size, water source number and locations, and stock density/herd size could all influence the amount of time cattle are concentrated into pasture corners or near water, and deserve further consideration. Management of fences, water sources, and herd location and size in a manner that rotates the location of cattle concentration areas on the landscape could improve rangeland $\mathrm{N}$ balance if such management allows for periodic plant recovery and suffi- 
ciently reduces cattle $\mathrm{N}$ redistribution below the levels that we measured. For example, dairy cattle grazing in a smaller pasture with much higher stocking density than in our study had a more uniform distribution of dung and urine deposition relative to pasture corners, and not as extreme a concentration of excreta around the water source (White et al. 2001).

Given the pasture configuration we studied and atmospheric $\mathrm{N}$ inputs on the order of $5 \mathrm{~kg} \mathrm{~N} \cdot \mathrm{ha}^{-1} \cdot \mathrm{yr}^{-1}$, we predict that shortgrass rangeland grazed at stocking rates consistently greater than $0.7 \mathrm{AUM} \cdot \mathrm{ha}^{-1}$ will gradually be depleted of $\mathrm{N}$. Given that ongoing increases in atmospheric $\left(\mathrm{CO}_{2}\right)$ can intensify $\mathrm{N}$ limitations to forage production and quality (Milchunas et al. 2005; Dijkstra et al. 2010), management of cattle-mediated $\mathrm{N}$ fluxes should be recognized as one means to influence long-term sustainability of semiarid rangelands.

\section{ACKNOWLEDGMENTS}

We thank Mary Ashby, Tammy Kanode, Troy Smith, and Jeff Thomas for their dedicated work measuring cattle weight gains. We thank Pat McCusker for assistance with the GPS collaring study. We thank Judy Hendricks, Nicole Kaplan, and the many field assistants who measured plant biomass and $\mathrm{N}$ content.

\section{LITERATURE CITED}

Auerswald, K., F. Mayer, and H. Schnyder. 2009. Coupling of spatial and temporal pattern of cattle excreta patches on a low intensity pasture. Nutrient Cycling in Agroecosystems 88:275-288.

Augustine, D. J. 2003. Long-term, livestock-mediated redistribution of nitrogen and phosphorus in an East African savanna. Journal of Applied Ecology 40:137-149.

Balley, D., J. Gross, E. Laca, L. Rittenhouse, M. Coughenour, D. Swift, and P. Sims. 1996. Mechanisms that result in large herbivore grazing distribution patterns. Journal of Range Management 49:386-400.

Burke, I., W. Lauenroth, M. Vinton, P. Hook, R. Kelly, H. Epstein, M. Aguiar, M. Robles, M. Agullera, M. Murphy, and R. Gill. 1998. Plant-soil interactions in temperate grasslands. Biogeochemistry 42:121-143.

Burke, I., A. Mosier, P. Hook, D. Milchunas, J. Barrett, M. Vinton, R. McCulley, J. Kaye, R. Gill, H. Epstein, R. Kelly, W. Parton, C. Yonker, P. Lowe, and W. Lauenroth. 2008. Soil organic matter and nutrient dynamics of shortgrass steppe ecosystems. In: W. Lauenroth and I. C. Burke [EDS.]. Ecology of the shortgrass steppe: a long-term perspective. New York, NY, USA: Oxford University Press. p. 306-341.

CLARK, F. 1977. Internal cycling of nitrogen in shortgrass prairie. Ecology 58:13221333.

Coughenour, M. 1991. Spatial components of plant-herbivore interactions in pastoral, ranching, and native ungulate ecosystems. Journal of Range Management 44:530-542.

Dean, R., J. Ellis, R. Rice, and R. Bement. 1975. Nutrient removal by cattle from a shortgrass prairie. Journal of Applied Ecology 12:25-29.

Dijkstra, F., D. Blumenthal, J. Morgan, E. Pendall, Y. Carrillo, and R. Follett. 2010. Contrasting effects of elevated $\mathrm{CO}_{2}$ and warming on nitrogen cycling in a semiarid grassland. New Phytologist 187:426-437.

GansKopp, D. C., AND D. W. BoHnert. 2009. Landscape nutritional patterns and cattle distribution in rangeland pastures. Applied Animal Behaviour Science 116:110119.

Holland, E. A., F. J. Dentener, B. H. Braswell, and J. M. Sulzman. 1999. Contemporary and pre-industrial global reactive nitrogen budgets. Biogeochemistry 46:7-43.

Hook, P., AND I. C. BuRKE. 2000. Biogeochemistry in a shortgrass landscape: control by topography, soil texture and microclimate. Ecology 81:2686-2703.
Hyder, D., R. Bement, E. Remmenga, And D. Hervey. 1975. Ecological responses of native plants and guidelines for management of shortgrass range. Washington, DC, USA: USDA-ARS. Technical Bulletin No. 1503. 87 p.

King, J. Y., A. R. Mosier, J. A. Morgan, D. R. LeCain, D. G. Mlichunas, and W. J. Parton. 2004. Plant nitrogen dynamics in shortgrass steppe under elevated atmospheric carbon dioxide. Ecosystems 7:147-160.

LANGe, R., AND M. Willcocks. 1978. The relation between sheep-time spent and egesta accumulated within an arid zone paddock. Australian Journal of Experimental Agriculture and Animal Husbandry 18:764-767.

Lauenroth, W. K., I. C. Burke, and M. P. Gutmann. 1999. The structure and function of ecosystems in the central North American grassland region. Great Plains Research 9:223-260.

LeBauer, D. S., and K. K. Treseder. 2008. Nitrogen limitation of net primary productivity in terrestrial ecosystems is globally distributed. Ecology 89:371379.

MlLchunas, D. G., and W. K. Lauenroth. 1992. Carbon dynamics and estimates of primary production by harvest, ${ }^{14} \mathrm{C}$ dilution, and ${ }^{14} \mathrm{C}$ turnover. Ecology 73:593607.

Milchunas, D. G., A. R. Mosier, J. A. Morgan, D. R. LeCain, J. Y. King, and J. A. Nelson. 2005. Elevated $\mathrm{CO}_{2}$ and defoliation effects on a shortgrass steppe: forage quality versus quantity for ruminants. Agriculture, Ecosystems and Environment 111:166-184.

Milchunas, D., W. Parton, D. Bigelow, and D. S. Schimel. 1988. Factors influencing ammonia volatilization from urea in soils of the shortgrass steppe. Journal of Atmospheric Chemistry 6:323-340.

Moir, J. L., K. C. Cameron, H. J. Di, and U. Fertsak. 2011. The spatial coverage of dairy cattle urine patches in an intensively grazed pasture system. Journal of Agricultural Science 149:473-485.

Mosier, A., W. Parton, R. Martin, D. Valentine, D. OJima, D. Schimel, I. Burke, E. Adair, and S. Del Grosso. 2008. Soil-atmosphere exchange of trace gases in the Colorado shortgrass steppe. In: W. Lauenroth and I. C. Burke [EDS.]. Ecology of the shortgrass steppe: a long-term perspective. New York, NY, USA: Oxford University Press. p. 389-446.

Mosier, A. R., W. J. Parton, D. W. Valentine, D. S. OJima, D. S. Schimel, and J. A. Delgado. 1996. $\mathrm{CH}_{4}$ and $\mathrm{N}_{2} \mathrm{O}$ fluxes in the Colorado shortgrass steppe: 1. impact of landscape and nitrogen addition. Global Biogeochemical Cycles 10:387-399.

Mosier, A. R., W. J. Parton, D. W. Valentine, D. S. OJima, D. S. Schimel, and 0. HeINemeYer. 1997. $\mathrm{CH}_{4}$ and $\mathrm{N}_{2} \mathrm{O}$ fluxes in the Colorado shortgrass steppe: 2 . long term impact of land use change. Global Biogeochemical Cycles 11:29-42.

Pineiro, G., J. M. Paruelo, M. Oesterheld, and E. G. Jobbagy. 2010. Pathways of grazing effects on soil organic carbon and nitrogen. Rangeland Ecology \& Management 63:109-119.

Reich, P. B., S. E. Hobbie, T. Lee, D. S. Ellsworth, J. B. West, D. Tilman, J. M. H. Knops, S. NAEEM, AND J. TROSt. 2006. Nitrogen limitation constrains sustainability of ecosystem response to $\mathrm{CO}_{2}$. Nature 440:922-925.

Schimel, D. S., W. Parton, F. Adamsen, R. G. Woodmansee, R. Senft, and M. A. Stillwell. 1986. The role of cattle in the volatile loss of nitrogen from a shortgrass steppe. Biogeochemistry 2:39-52.

SCHNydeR, H., F. LOCHER, AND K. Auerswald. 2010. Nutrient redistribution by grazing cattle drives patterns of topsoil $\mathrm{N}$ and $\mathrm{P}$ stocks in a low-input pasture ecosystem. Nutrient Cycling in Agroecosystems 88:183-195.

Senft, R. 1983. The redistribution of nitrogen by cattle. Fort Collins, CO, USA: Colorado State University. $151 \mathrm{p}$.

Ungar, E. D., Z. Henkin, M. Gutman, A. Dolev, A. Genizi, and D. Ganskopp. 2005. Inference of animal activity from GPS collar data on free-ranging cattle. Rangeland Ecology \& Management 58:256-266.

Van Uytvanck, J., T. Milotic, and M. Hoffmann. 2010. Nitrogen depletion and redistribution by free-ranging cattle in the restoration process of mosaic landscapes: the role of foraging strategy and habitat proportion. Restoration Ecology 18:201-216.

White, S. L., R. E. Sheffield, S. P. Washburn, and L. D. King. 2001. Spatial and time distribution of dairy cattle excreta in an intensive pasture system. Journal of Environmental Quality 30:2180-2187.

Zachariassen, J., And D. S. Schimel. 1991. Ammonia exchange above grassland canopies. EOS Transactions, American Geophysical Union 72:110. 